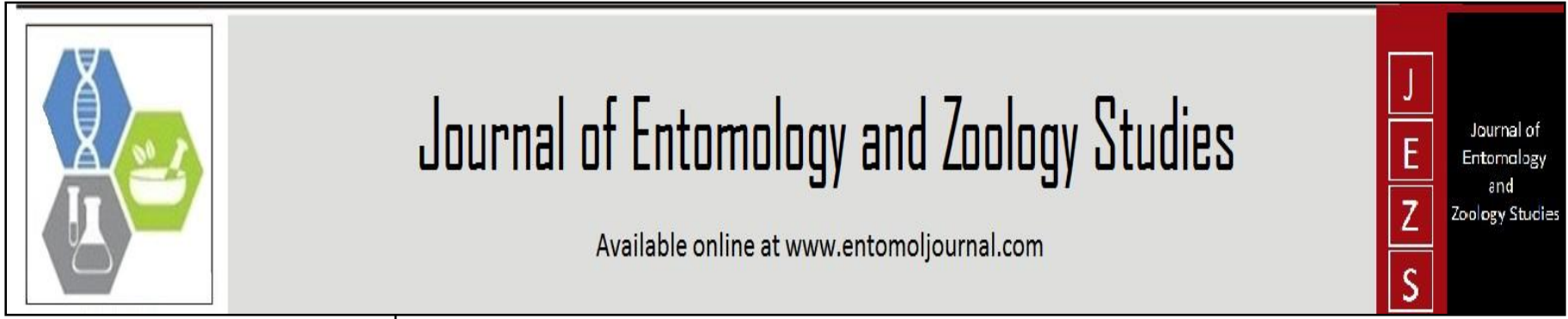

E-ISSN: 2320-7078

P-ISSN: 2349-6800

www.entomoljournal.com

JEZS 2020; 8(5): 1674-1680

(C) $2020 \mathrm{JEZS}$

Received: 20-07-2020

Accepted: 25-08-2020

\section{Avijit Biswas}

Assistant Professor, School of Fisheries, Centurion University of Technology and Management, Odisha, India

Dr. Gadadhar Dash

Professor, Department of Aquatic Animal Health, Faculty of Fishery Sciences, West Bengl Unery West Bengal, India

\section{Prasenjit Mali}

Assistant Professor, Department of Aquatic Animal Health, Faculty of Fishery Science West Bengal University of Animal and Fishery Sciences, Chakgaria, Panchasayar, Kolkata, West Bengal, India

Dr. Siddhartha Narayan Joardar Professor, Department of Veterinary Microbiology, Faculty of Veterinary and Animal Sciences West Bengal University of Animal and Fishery Sciences, Kshudiram Bose Sarani, Belgachia, Kolkata, West Bengal, India

Dr. T Jawahar Abraham

Professor, Department of Aquatic Animal Health, Faculty of Fishery Scies, West Bengal Uive Bengl Uni Sciences, Chakgaria, Panchasayar, Kolkat
West Bengal, India

\section{Sutanu Karmaka}

Assistant Professor, Department of Aquatic Environment Management, Faculty of Fishery Sciences, West Bengal University of Animal and Fishery Sciences, Chak Panchasayar, Kolkata, West Bengal, India

\section{Debapriyo Mukherjee}

Senior Research Fellow, Nation Surveillance Programme for Aquatic Animal Diseases, Department of Aquatic Animal Health, Faculty of Fishery Science West Bengal University of Animal and Fishery Sciences, Chakgaria, Panchasayar, Kolkata, West Bengal, India

\section{Dr. Koel Bhattacharya Sanyal} Senior Re Surveillaue Program, Nato Aquac Survillace Progratic Animal Diseases, Department of Aquatic Animal Health, Faculty of Fishery Scienc West Bengal University of Animal and Fishery Sciences, Kolkata, West Bengal, India

\section{Vaccine potentiality of different antigenic preparations of Aeromonas hydrophila in Rohu, Labeo rohita Ham}

\section{Avijit Biswas, Dr. Gadadhar Dash, Prasenjit Mali, Dr. Siddhartha Narayan Joardar, Dr. T Jawahar Abraham, Sutanu Karmakar, Debapriyo Mukherjee and Dr. Koel Bhattacharya Sanyal}

\author{
DOI: https://doi.org/10.22271/j.ento.2020.v8.i5w.7738
}

\begin{abstract}
To develop vaccine for rohu (Labeo rohita), efficacy of three antigenic preparations from Aeromonas hydrophila were evaluated. Thirty six tanks with ten rohu were divided in quadruplicates ( $\mathrm{R}_{1}$ to $\left.\mathrm{R}_{4}\right)$ with nine tanks $\left(\mathrm{G}_{1}\right.$ to $\left.\mathrm{G}_{9}\right)$. Rohu of $\mathrm{G}_{1}$ to $\mathrm{G}_{6}$ tanks were given intraperitoneal vaccine with outer membrane protein, somatic protein and formalin-inactivated whole cell itself and along with Incomplete Freund's Adjuvant @ $200 \mu \mathrm{g} /$ fish, G7 and G8 tanks were injected with Incomplete Freund's Adjuvant (100 $\mu 1 /$ fish) and normal saline $\left(100 \mu \mathrm{l} /\right.$ fish) respectively and $\mathrm{G}_{9}$ tanks were kept as control. After $28 \mathrm{~d}$, rohu of $\mathrm{R}_{3}$ and $\mathrm{R}_{4}$ were subjected to intramuscular A. hydrophila challenge (LD50) @ $2.85 \times 10^{6}$ cells/fish for $7 \mathrm{~d}$ and RPS (\%) was calculated. Specific cellular and humoral immune responses were determined for rohu of $\mathrm{R}_{1}$ and $\mathrm{R}_{2}$. Results showed that rohu immunized with outer membrane protein along with adjuvant could offer an appropriate vaccine strategy.
\end{abstract}

Keywords: Aeromonas hydrophila, rohu, vaccine, specific immune response

\section{Introduction}

Aquaculture apart from being a most promising sector, it provides high quality protein, generates income, employment and foreign exchange around the globe. Global fish production has reached to about 178.5 million tons with inland aquaculture representing $28.73 \%$ of total production (FAO) ${ }^{[11]}$. In India, freshwater fish culture practices mainly constitute the culture of Indian major carps namely, catla (Catla catla), rohu (Labeo rohita) and mrigal (Cirrhinus mrigala). Carp culture constitutes more than $80 \%$ of total aquaculture production of India (Jaysankar) ${ }^{[14]}$ out of which Labeo rohita commonly known as rohu, is most prominent among others due to its high growth potential coupled with high consumer preferences and high nutritive value. Like other freshwater fishes rohu can be infected by different pathogens, microorganisms or parasites. The bacterial infections are considered the major factors of mass mortality in farmed and wild fish. Aeromonas hydrophila is considered as most common bacterial pathogen in rohu, and has been considered as causative agent of several distinct pathological situations including swelling of tissues, necrosis, ulceration, tail/fin rot, motile aeromonas septicemia or haemorrhagic septicemia as a primary pathogen (Hu et al. $)^{[13]}$, (Rasmussen et al. $)^{[22]}$.

During the past decades, a lot of efforts have been given for immunization of fish with the vaccines. It has been already established that the improvement of a suitable vaccine approach have successfully given protection to the teleost against different infectious diseases caused by pathogen (Uribe et al.) ${ }^{[32]}$, (Gudding and Muiswinkel) ${ }^{[12]}$, (Bøgwald and Dalmo) ${ }^{[4]}$. It is well known that fish are equipped with immunological properties and are quite able to raise competent protection against invading pathogens. Particularly a proper knowledge of acquired immune response in fish is urgently needed for the betterment of defensive strategies to combat against fish diseases in the aquaculture sector. Several attempts had been made by different scientist for immunization of rohu against Aeromonas hydrophila infection

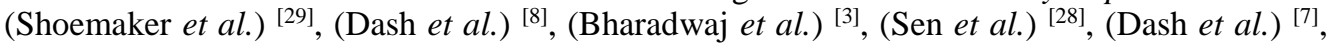
(Dubey et al.) ${ }^{[9]}$. Till date many efforts have been made to develop vaccines throughout world, from inactivated products and live attenuated organisms to advancement high tech vaccines against $A$. hydrophila in different fish species (Mzula et al.) ${ }^{[19]}$ but till now suitable 
immunoprophylactic tool(s) are not commercially available to prevent Aeromonas hydrophila infection of rohu. Hence, in the present study rohu (Labeo rohita) has been taken as the species of concern to assess the efficacy and vaccine effectiveness among outer membrane protein antigen, somatic protein antigen and formalin killed whole-cell protein antigen preparations of Aeromonas hydrophila.

\section{Materials and Methods}

2.1. Collection of $\boldsymbol{A}$. hydrophila strain: The bacterial strain Aeromonas hydrophila N10P (NCBI accession number KC914628) was obtained from the Department of Aquatic Animal Health, Faculty of Fishery Sciences, WBUAFS, Kolkata. The cell suspension of A. hydrophila N10P was prepared and checked by spread plating on Tryptone soya agar after incubation at $30^{\circ} \mathrm{C}$ for $24 \mathrm{~h}$. The $\mathrm{LD}_{50}$ value on $7 \mathrm{~d}$ of $A$. hydrophila N10P was calculated following the method of Reed and Muench ${ }^{[23]}$ to determine the pathogenicity.

\subsection{Preparation of bacterial antigens}

2.2.1. A. hydrophila N10P Whole-cell antigen: The wholecell antigen of $A$. hydrophila N10P strain was prepared as described by Kamilya et al. ${ }^{[15]}$ with some modifications. The cell suspension of $A$. hydrophila was treated with formalin to a final concentration of $0.5 \%(\mathrm{v} / \mathrm{v})$ and left overnight at $4{ }^{\circ} \mathrm{C}$. Washed with sterile phosphate buffer saline (PBS, HiMedia, $\mathrm{pH}$ 7.2) and checked for sterility by streaking on to TSA plates. The washed formalin-killed bacterial cells were resuspended in $5 \mathrm{ml}$ PBS and stored at $4^{\circ} \mathrm{C}$ until used.

\subsubsection{A. hydrophila N10P somatic antigen: A. hydrophila} N10P culture in $10 \mathrm{ml}$ tryptic soy broth (HiMedia, India) were subjected to heat killing by incubating at hot water bath at $60^{\circ} \mathrm{C}$ for $1 \mathrm{~h}$ after addition of $25 \mathrm{mM}$ Phenylmethylsulfonyl fluoride (Sigma) and $24 \mathrm{mM}$ Ethylenediaminetetra-acetic acid (Sigma). The sonication of said culture was conducted on the ice at $60 \mathrm{~W}$ with repeating duty cycle of $0.5 \mu$ for 10 times 1 $\mathrm{m}$ each with $1 \mathrm{~m}$ interval using an ultrasonicator (Labsonic $\AA$ $\mathrm{U}$, Biotech International). After that the soluble sonicated extracts were centrifuged at $3500 \mathrm{~g}$ for $30 \mathrm{~m}$ at $4{ }^{\circ} \mathrm{C}$. The soluble supernatant was filter-sterilized $(0.22 \mu)$ and the filtrates were stored at $-20^{\circ} \mathrm{C}$ as somatic antigens.

\subsubsection{A. hydrophila N10P outer membrane protein} antigen: Bacterial outer membrane proteins were obtained by the method of Mali et al. ${ }^{[18]}$ with some modifications. The pellets, obtained from the centrifugation after sonication, were washed and re-suspended in $20 \mathrm{ml}$ sterile phosphate buffer saline (PBS, HiMedia, $\mathrm{pH}$ 7.2). This suspension was treated with $2 \%$ sodium dodecyl sulphate and $2 \%$ mercaptoethanol for $20 \mathrm{~m}$ at $60{ }^{\circ} \mathrm{C}$ for solubilization. The extracts were centrifuged at $3500 \mathrm{~g}$ for $30 \mathrm{~m}$ at $4^{\circ} \mathrm{C}$ and the supernatant was filtered through $0.22 \mu$ membrane filter and stored at $-20{ }^{\circ} \mathrm{C}$ until use.

\subsection{Acclimatization of experimental fish: Clinically} healthy, 80-100 g rohu were obtained from a commercial fish farm in Sonarpur, West Bengal, India. The fishes were disinfected by 5 ppm $\mathrm{KMnO}_{4}$ for $15 \mathrm{~m}$ and were shifted to ten circular fiberglass tanks of 5001 capacity @ 50 rohu/ tank. During acclimatization they were fed twice daily at the rate of $1 \%$ of the body weight by commercial floating dry pellet diet containing of $30 \%$ protein and $2 \%$ vitamins minerals mixture. Continuous aeration was provided and the fishes were maintained for 3 weeks before to the experiment.

2.4. Experimental design: The experiments were carried out in the wet laboratory of Faculty of Fishery Sciences, West Bengal University of Animal and Fishery Sciences facilitated with $24 \mathrm{~h}$ water supply, drainage system, ventilation and transparent sheet roof for providing adequate light. The fibreglass tanks were scrubbed and cleaned with chlorinated water $(200 \mathrm{ppm})$. Overhead tank water was used throughout the experiment and the basic physicochemical water parameters were maintained at the optimal throughout the experiment as Sahoo et al. ${ }^{[25]}$. The ambient temperature of the wet laboratory during the trial was in the range of 25$30^{\circ} \mathrm{C}$. Fibreglass rectangular tanks $(n=36)$ of 3001 capacity were filled with clean water up to volume 2501 and conditioned for $3 \mathrm{~d}$. Tanks were stocked with experimental fishes from the acclimatized stocks. The rohu were stocked @ 10 numbers in each tank and were acclimatized for $7 \mathrm{~d}$. After acclimatization, the tanks were divided in quadruplicates viz. $R_{1}, R_{2}, R_{3}$ and $R_{4}$ having nine tanks $\left(G_{1}, G_{2}, G_{3}, G_{4}, G_{5}, G_{6}\right.$, $\mathrm{G}_{7}, \mathrm{G}_{8}$ and $\mathrm{G}_{9}$ ) in each group. Among $\mathrm{R}_{1}$ to $\mathrm{R}_{4}$, fishes of each six tanks $\left(G_{1}\right.$ to $\left.G_{6}\right)$ were vaccinated intraperitoneally with different bacterial antigens @ $200 \mu \mathrm{g} / \mathrm{fish}$, fishes of all $\mathrm{G}_{7}$ and $\mathrm{G}_{8}$ tanks each were injected intraperitoneally with Incomplete Freund's Adjuvant $(100 \mu \mathrm{l} /$ fish $)$ and normal saline solution (100 $\mu 1 /$ fish), respectively and remaining $\mathrm{G}_{9}$ tanks were kept without injection as control. Fishes of all $G_{1}$ and $G_{2}$ tanks each were injected with outer membrane protein antigen itself and along with equal volume of Incomplete Freund's Adjuvant respectively. Similarly, fishes of $\mathrm{G}_{3}$ and $\mathrm{G}_{4}$ tanks were injected with somatic antigen itself and along with Incomplete Freund's Adjuvant, whereas whole-cell protein antigen was injected only and also with Incomplete Freund's Adjuvant into the rohu of $\mathrm{G}_{5}$ and $\mathrm{G}_{6}$ tanks respectively. The immunized fishes of all four groups $\mathrm{R}_{1}$ to $\mathrm{R}_{4}$ were maintained in their respective tank for $28 \mathrm{~d}$.

After $28^{\text {th }} \mathrm{d}$, fishes of $\mathrm{R}_{1}$ and $\mathrm{R}_{2}$ groups (from all $\mathrm{G}_{1}$ to $\mathrm{G}_{9}$ tanks) were taken out for assessment of post vaccination humoral and cellular immune responses. Fish sera were collected from the half of immunized fishes of both $\mathrm{R}_{1}$ and $\mathrm{R}_{2}$ groups and were pooled for different treatment groups before storing at $-20^{\circ} \mathrm{C}$. Remaining halves of fishes were dissected for isolation of head kidney leukocytes for in vitro cellular assay. While the fishes of $\mathrm{R}_{3}$ and $\mathrm{R}_{4}$ group were challenged with $A$. hydrophila N10P for $7 \mathrm{~d}$. Each fish of $\mathrm{R}_{3}$ and $\mathrm{R}_{4}$ were injected intramuscularly with $0.1 \mathrm{ml}$ of $A$. hydrophila N10P cell suspension $\left(2.85 \times 10^{6}\right.$ cells/fish). Mortality, external signs of infection and behavioural changes were recorded daily and Relative Percentage of Survival (RPS\%) was estimated after 7 d.

RPS $(\%)=\left(1-\frac{\% \text { mortality in vaccinated rohu }}{\% \text { mortality in control rohu }}\right) \times 100$

2.5. Isolation of rohu immunoglobulin from sera: Blood was collected aseptically from 25 live rohu and sera were separated. Sera from all the rohu were pooled, as they were homologous in nature. Five millilitres of sera were taken for the isolation of immunoglobulin using $40 \%$ saturated ammonium sulphate. Three milliliter of immunoglobulin was harvested and stored at $-20^{\circ} \mathrm{C}$ in aliquots for further use. The protein content of the isolated rohu immunoglobulin was estimated using the standard protocol of Lowry et al. ${ }^{[16]}$ with some modification. 
2.6. Raising of hyper-immune sera against rohu immunoglobulin: Hyperimmunisation of New Zealand white rabbit for preparation of anti-rohu rabbit immunoglobulin was carried out (Sahoo and Joardar) ${ }^{[24]}$. Four doses of rohu immunoglobulin and Freund's adjuvant (Sigma, USA) (1:1) were injected intramuscularly. The hyper-immune sera was collected after $5 \mathrm{~d}$ of the last injection and stored at $-20{ }^{\circ} \mathrm{C}$. Specificity between rohu-immunoglobulin and anti-rohu rabbit immunoglobulin and the titre of anti-rohu rabbit immunoglobulin was assessed by an immunodiffusion test (Ouchterlony) [20] with some modifications and countercurrent immunoelectrophoresis as per Sardar et al. ${ }^{[27]}$.

2.7.1. Coupling of horseradish peroxidase enzyme with anti-rohu rabbit immunoglobulin: Glutaraldehyde method (Sahoo and Joardar) [24] was performed for linking of horseradish peroxidase (HRPO) enzyme with anti-rohu rabbit immunoglobulin. Specificity and titre of the anti-rohu rabbit enzyme immunoconjugate were determined by direct ELISA as per Sahoo and Joardar ${ }^{[24]}$.

2.7.2. Assessment of anti-Aeromonas hydrophila antibodies in rohu by indirect plate ELISA: Enzyme-linked immunosorbent assay was performed as per Sahoo and Joardar [24] with some modifications to assess the antiAeromonas hydrophila antibodies in all $\mathrm{G}_{1}$ to $\mathrm{G}_{9}$ tanks of $\mathrm{R}_{1}$ and $\mathrm{R}_{2}$ rohu groups. In brief, different antigens i.e., outer membrane protein antigen, somatic protein antigen and whole cell protein antigen were coated in triplicate into 96 wells ELISA plate (Tarsons, India) at a concentration of $2 \mu \mathrm{g} /$ well along with carbonate-bicarbonate coating buffer ( $\mathrm{pH} 9.6$ ). The pooled diluted sera $(1: 200)$ of vaccinated rohu $\left(G_{1}\right.$ to $\left.G_{6}\right)$, Incomplete Freund's Adjuvant and normal saline solution injected rohu $\left(\mathrm{G}_{7}\right.$ and $\left.\mathrm{G}_{8}\right)$ and control rohu $\left(\mathrm{G}_{9}\right)$ were added @ $100 \mu \mathrm{l} /$ well and incubated for $2 \mathrm{~h}$ at $37^{\circ} \mathrm{C}$. Diluted (1:500 in PBS) anti-rohu rabbit HRPO immune conjugate (Laboratory prepared) was applied and incubated for $2 \mathrm{~h}$ at $37^{\circ} \mathrm{C}$. After washing, a substrate solution $\left(5 \mu 1 \mathrm{H}_{2} \mathrm{O}_{2}, 0.025\right.$ $\mathrm{mg}$ o-phenylene diamine dihydrochloride in $25 \mathrm{ml}$ citrate buffer) was added (100 $\mu \mathrm{l} /$ well). The colour development was noticed after $30 \mathrm{~m}$ and reading was taken at $492 \mathrm{~nm}$ using an ELISA reader (ECIL, India) after addition of stopper solution $\left(3 \mathrm{~N} \mathrm{H}_{2} \mathrm{SO}_{4}\right)$.

2.7.3. MTT dye assay: MTT dye assay was performed (Maji et $a$. .) ${ }^{[17]}$ to quantify the proliferative responses of rohu kidney lymphocytes in all rohu $\left(G_{1}\right.$ to $\left.G_{9}\right)$ of $R_{1}$ and $R_{2}$ groups. First, the head kidney leucocyte of experimental fish was isolated (Kamilya et al.) ${ }^{[15]}$.

2.7.4. Mitogens and Antigens: Initially, the stock solution of concanavalin A (Sigma) was prepared at the concentration of $20 \mu \mathrm{g} / \mathrm{ml}$ of the proliferation medium (RPMI-1640, growth medium), membrane filtered $(0.22 \mu \mathrm{m})$ and stored at $-20{ }^{\circ} \mathrm{C}$ for use. Stock solution $(80 \mu \mathrm{g} / 100 \mu \mathrm{l})$ of outer membrane protein antigen, somatic protein antigen and whole cell protein antigen of $A$. hydrophila were prepared in phosphate buffer saline, membrane filtered $(0.22 \mu \mathrm{m})$ and stored at -20 ${ }^{\circ} \mathrm{C}$ for use.

2.7.5. In-vitro lymphocyte proliferation assay: Cell separation of head kidney leucocytes $\left(5 \times 10^{5}\right.$ cells $\left./ \mathrm{ml}\right)$ of all rohu $\left(G_{1}\right.$ to $\left.G_{9}\right)$ of $R_{1}$ and $R_{2}$ groups were pooled and suspended in RPMI-1640. Hundred $\mu$ l of said cell suspension were seeded into every well of 96 -well tissue culture plates in triplicate. The ultimate volume of the wells was ended up to $200 \mu \mathrm{l}$ with outer membrane protein antigen, somatic protein antigen and whole cell protein antigen at a concentration of 40 $\mu \mathrm{g} / 100 \mu \mathrm{l}$ and Con-A at a concentration of $10 \mu \mathrm{g} / 100 \mu \mathrm{l}$. In control well, only $100 \mu 1$ RPMI-1640 were added to make the ultimate volume $200 \mu \mathrm{l}$. The plate was incubated at $28^{\circ} \mathrm{C}$ for $48 \mathrm{~h}$ containing $5 \% \mathrm{CO}_{2}$ tension.

The colourimetric 3 - [4, 5 - dimethylthiazol-2-yl $]$ - 2, 5 diphenyltetrazolium bromide (MTT) assay (Maji et al.) ${ }^{[17]}$ was used to verify the head kidney leucocytes proliferation. After $48 \mathrm{~h}$ of culture, the plate was again incubated at $28^{\circ} \mathrm{C}$ for $4 \mathrm{~h}$ after addition of $20 \mu \mathrm{l}$ of MTT $(5 \mathrm{mg} / \mathrm{ml}$ in PBS) to each well. The formazan production was estimated by the method of Plumb et al. ${ }^{[21]}$ with minor modifications. The plate was centrifuged at $50 \mathrm{~g}$ for $10 \mathrm{~m}$ followed by removal of the supernatant fluids without disturbing the cell pellet or formazan precipitate. The formazan crystals were dissolved by the consecutive addition of $150 \mu 1$ of Dimethyl sulfoxide (Sigma) and $25 \mu \mathrm{l}$ of glycine buffer $(0.1 \mathrm{M}$ glycine, $0.1 \mathrm{M}$ $\mathrm{NaCl}, \mathrm{pH} 10.5)$. The plate was incubated at room temperature for $10 \mathrm{~m}$. The formazan development was measured at 595 nm (Maji et al.) ${ }^{[17]}$ using a plate reader (ECIL, India). Stimulation index was calculated by the following formula-

S. I. $=\left(\frac{\text { Mean optical density of sensitized lymphocyte wells with Con }- \text { A or antigen }}{\text { Mean optical density of control lymphocyte wells }}\right)-1$

2.8. Statistical analysis: The results of each experiment are expressed as the mean \pm standard deviation and analyzed by one-way analysis of variance (ANOVA) using the Statistical Package for Social Sciences (IBM-SPSS); Version 22.0 to test the significance of the difference between the control and experimental groups.

\section{Results and Discussion}

3.1. Anti-rohu rabbit enzyme immunoconjugate assessment: The calculated protein value of the rohu immunoglobulin and anti-rohu rabbit immunoglobulin was found $1.35 \mathrm{mg} / \mathrm{ml}$ and $2.08 \mathrm{mg} / \mathrm{ml}$, respectively. Immunodiffusion test and Countercurrent immunoelectrophoresis results confirmed the specificity of anti-rohu rabbit immunoglobulin with the rohu immunoglobulin, which corroborates earlier observation (Das et al.) ${ }^{[6]}$. The titre of anti-rohu rabbit immunoglobulin was found four. During assessment of specificity of anti-rohu rabbit enzyme immunoconjugate to rohu-Ig by direct ELISA, the highest optical density value of 0.507 was found in diluted (1:500) anti-rohu rabbit HRPO immunoconjugate which was more or less similar to Sahoo and Joardar [24] and was found as an effective serodiagnostic tool in rohu.

3.2. Virulence study of Aeromonas hydrophila: The Aeromonas hydrophila N10P strain was found to be virulent as the intramuscular challenge in rohu $(100 \pm 10 \mathrm{~g})$ at $2.2 \times 10^{9}$, $2.2 \times 10^{8}$ and $2.2 \times 10^{7}$ cells/fish recorded $100 \%$ mortality within $12 \mathrm{hr}, 1 \mathrm{~d}$ and $4 \mathrm{~d}$ of challenge respectively. Mortality started at $5 \mathrm{~d}$ of post-challenge in $2.2 \times 10^{6}$ cells/fish. The $\mathrm{LD}_{50}$ value of $A$. hydrophila N10P (NCBI accession number KC914628) of $7 \mathrm{~d}$ was found $2.85 \times 10^{6}$ cells/fish. The biochemical test results of the bacterium isolated from the moribund fishes confirmed the A. hydrophila infection. 
3.3. Gross clinical signs, mortality and relative percentage of survival (\%) during experiment: No mortality was observed in all tanks $\left(\mathrm{G}_{1}\right.$ to $\left.\mathrm{G}_{9}\right)$ of $\mathrm{R}_{1}$ to $\mathrm{R}_{4}$ groups during 28 days of the experiment except few clinical signs. Few pinpoint hemorrhages were noticed in only thirteen rohu out of all groups of quadruplicates tank injected with outer membrane protein antigen, somatic protein antigen, whole cell protein antigen itself and whole cell protein antigen along with Freund's incomplete adjuvant. Those gross clinical changes observed during 28-days vaccination might be due to the pathogenic effects of virulent $A$. hydrophila N10P. During $7 \mathrm{~d}$ A. hydrophila challenge for $\mathrm{R}_{3}$ and $\mathrm{R}_{4}$ groups, $81.81 \%$ RPS (Fig.1) was found in case of fishes vaccinated with both outer membrane protein antigen and somatic protein antigen mixed with equal volume of Incomplete Freund's Adjuvant. In both cases, less than $25 \%$ of rohu showed minute clinical signs like ulceration patches on body. Fishes immunized with outer membrane protein antigen, somatic protein antigen itself and whole-cell protein antigen along with Incomplete Freund's Adjuvant showed 63.63\% RPS (Fig.1) with clinical signs like pinpoint hemorrhages and ulceration patches on body for less than $30 \%$ rohu. Whereas, $45.45 \%$ RPS (Fig.1) were noticed in case of fishes injected with whole-cell protein antigen itself but number of fishes clinically infected was $45 \%$ of population. Relative percentage of survival was found nil for the Incomplete Freund's Adjuvant injected, normal saline solution injected and control rohu where $70-90 \%$ of fishes showed extensive clinical signs with head lesion, fin rot and tail rot, ulceration and hemorrhages on skin with 55-60\% mortality. Our results differed from the observations of Sen $e t$ al. [28] where they observed highest relative percentage survival in formalin killed whole-cell A. hydrophila along with adjuvant vaccinated rohu after 60 days post-challenge. Sun et al. ${ }^{[30]}$ observed highest relative percent survival in $A$. hydrophila immunized grass carp (Ctenopharyngodon idella) in the Lipopolysaccharide and outer membrane protein injected groups ( $83.3 \%$ and $72.2 \%$, respectively) but $90 \%$ fish died after challenge in phosphate buffer saline injected control group.

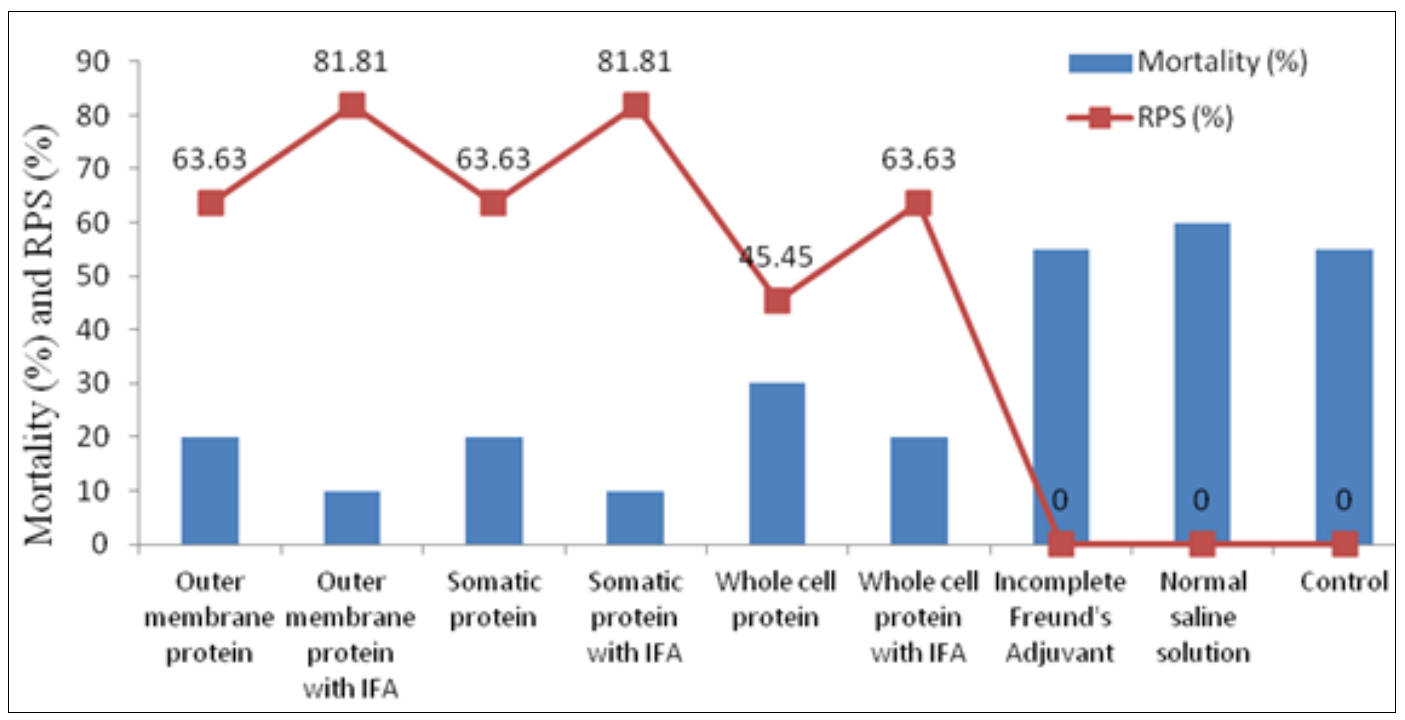

Fig 1: Mortality (\%) \& RPS (\%) after $7 \mathrm{~d}$ A. hydrophila challenge of vaccinated rohu

3.4. Assessment of specific humoral immune responses: While Assessing the specific humoral immunities in rohu by indirect ELISA after $28^{\text {th }}-\mathrm{d}$ post-vaccination, the sera collected from all vaccinated rohu showed reactivity to the laboratory prepared enzyme immune conjugate (1:500 dilution), i.e., anti-rohu rabbit hyperimmune sera coupled with HRPO. Among fish sera of all vaccinated, Incomplete Freund's Adjuvant injected, normal saline solution injected and control rohu groups after $28^{\text {th }} \mathrm{d}$ of post-vaccination, it was observed that there were significant differences $(P<0.05)$ of humoral responses in all six vaccinated fish groups compared to normal saline solution, Incomplete Freund's Adjuvant injected rohu and control rohu. The highest mean ( \pm S.D.) antibody level in terms of optical density value of $0.712 \pm 0.012$ and $0.722 \pm 0.019$ was recorded for outer membrane protein antigen along with Incomplete Freund's Adjuvant and whole cell antigen mixed with Incomplete Freund's Adjuvant vaccinated rohu, respectively after $28^{\text {th }} \mathrm{d}$ post-vaccination. Incomplete Freund's Adjuvant injected rohu $\left(\mathrm{G}_{7}\right)$ also showed higher significant difference $(P<0.05)$ in humoral responses than control $\left(\mathrm{G}_{9}\right)$. That confirmed boosting of specific humoral immune responses in all six vaccinated rohu as a result of successful vaccination. The results of the present studies were supported by the observations of Swain et al. [31] where they found enhancement of antibody production level in rohu by A. hydrophila mixed with other two bacterial whole-cell protein. Sen et al. ${ }^{[28]}$ also found the similar results where the antibody production of fish groups vaccinated with three different antigenic preparations like formalin inactivated A. hydrophila along with Incomplete Freund's Adjuvant, A. hydrophila itself and extracellular products enhanced the antibody production level $(P<0.05)$ compared with control. As per Bastardo et al. ${ }^{[1]}$ the degree of immune responses varies depending upon the type of vaccine used. We found that the antibody production in all vaccinated rohu significantly evoked antibody response $(P<0.05)$ than Incomplete Freund's Adjuvant injected, normal saline solution injected and control. Increased antibody production after vaccination against $A$. hydrophila was also observed in different Indian major carps (Chandran et al.) ${ }^{[5]}$, Kamilya et al. ${ }^{[15]}$, Saikia and Kamilya ${ }^{[26]}$. Now it is the time to say that the variation in responses of fish to A. hydrophila and its different antigenic preparation need to be evaluated thoroughly for the successful development of a vaccine for $A$. hydrophila in rohu. 
Table 1: OD values after $28^{\text {th }} \mathrm{d}$ post vaccination $\left(\mathrm{R}_{1}\right.$ and $\left.\mathrm{R}_{2}\right)$ as assessed by ELISA

\begin{tabular}{|c|c|c|c|c|c|}
\hline $\begin{array}{c}\text { Different } \\
\text { vaccinated rohu } \\
\text { group } \downarrow \\
\end{array}$ & $\begin{array}{c}\text { Antigens coated wells for } \\
\text { antibody production } \\
\text { assessment } \rightarrow\end{array}$ & $\begin{array}{c}\text { Outer membrane protein } \\
\text { coating @ } 2 \mu \mathrm{g} / \text { well of } \\
\text { ELISA plate }\end{array}$ & $\begin{array}{c}\text { Somatic protein } \\
\text { antigen coating @ } 2 \\
\mu \mathrm{g} / \text { well of ELISA plate }\end{array}$ & $\begin{array}{c}\text { Whole cell protein } \\
\text { antigen coating @ } 2 \\
\mu \mathrm{g} / \text { well of ELISA plate }\end{array}$ & $\begin{array}{c}\text { Without Antigen } \\
\text { coating well of } \\
\text { ELISA plate } \\
\end{array}$ \\
\hline \multicolumn{2}{|c|}{ Outer membrane protein } & $0.534^{\mathrm{g}^{\mathrm{C}} \pm 0.018}$ & $0.341^{\mathrm{c}}{ }^{\mathrm{B}} \pm 0.011$ & $0.380^{\mathrm{b} B} \pm 0.028$ & $0.138^{\mathrm{a} \mathrm{A}} \pm 0.022$ \\
\hline \multicolumn{2}{|c|}{$\begin{array}{c}\text { Outer membrane protein with Incomplete } \\
\text { Freund's Adjuvant }(1: 1)\end{array}$} & $0.712^{\mathrm{f}} \pm 0.012$ & $0.417^{\mathrm{d} \mathrm{B}} \pm 0.010$ & $0.393^{\mathrm{b}} \mathrm{B} \pm 0.019$ & $0.112^{\mathrm{a}} \mathrm{A}_{ \pm 0.010}$ \\
\hline \multicolumn{2}{|c|}{ Somatic protein antigen } & $0.408^{\mathrm{d} \mathrm{BC}} \pm 0.010$ & $0.483^{\mathrm{e}^{\mathrm{C}} \pm 0.032}$ & $0.335^{\mathrm{b}} \mathrm{B}_{ \pm 0.029}$ & $0.121^{\mathrm{a} A} \pm 0.013$ \\
\hline \multicolumn{2}{|c|}{$\begin{array}{c}\text { Somatic protein antigen with Incomplete } \\
\text { Freund's Adjuvant }(1: 1)\end{array}$} & $0.490^{\mathrm{e}_{ \pm}} \pm 0.009$ & $0.593^{\mathrm{f}} \mathrm{D}_{ \pm 0.011}$ & $0.348^{\mathrm{b}}{ }^{\mathrm{B}} \pm 0.011$ & $0.119^{\mathrm{a}} \mathrm{A}_{ \pm 0.011}$ \\
\hline \multicolumn{2}{|c|}{ Whole cell protein antigen } & $0.406^{\mathrm{d} \mathrm{C}_{ \pm}} \pm .010$ & $0.338^{\mathrm{c} B} \pm 0.015$ & $0.539^{\mathrm{c}} \pm 0.022$ & $0.124^{\mathrm{a} A} \pm 0.021$ \\
\hline \multicolumn{2}{|c|}{$\begin{array}{l}\text { Whole cell protein antigen with Incomplete } \\
\text { Freund's Adjuvant }(1: 1)\end{array}$} & $0.424^{\mathrm{d}} \mathrm{B}_{ \pm 0.010}$ & $0.427^{\mathrm{d} B} \pm 0.009$ & $0.722^{\mathrm{d}} \mathrm{C}_{ \pm 0} 0.019$ & $0.144^{\mathrm{a}}{ }_{ \pm} \pm .014$ \\
\hline \multicolumn{2}{|c|}{ Incomplete Freund's Adjuvant } & $0.351^{\mathrm{c}} \mathrm{C}_{ \pm 0.007}$ & $0.303^{\mathrm{bc} B} \pm 0.006$ & $0.335^{\mathrm{b}}{ }_{ \pm 0.004}$ & $0.119^{\mathrm{a}} \mathrm{A}_{ \pm 0.005}$ \\
\hline \multicolumn{2}{|c|}{ Normal saline solution } & $0.270^{\mathrm{b}} \mathrm{B}_{ \pm} 0.016$ & $0.259^{\mathrm{b}} \mathrm{B} \pm 0.021$ & $0.220^{\mathrm{a}} \mathrm{B}_{ \pm 0.016}$ & $0.121^{\mathrm{a}} \mathrm{A}_{ \pm} 0.008$ \\
\hline \multicolumn{2}{|c|}{ Control } & $0.204^{\mathrm{a}}{ }^{\mathrm{B}} \pm 0.014$ & $0.183^{\mathrm{a} \mathrm{B}} \pm 0.026$ & $0.215^{\mathrm{a}}{ }^{\mathrm{B}} \pm 0.017$ & $0.113^{\mathrm{a} \mathrm{A}_{ \pm} 0.010}$ \\
\hline
\end{tabular}

[Data $(n=3)$ are presented as mean \pm standard deviation. Values with different lower case letter superscripts differ significantly $(P<0.05)$ between the control and different treatment within the same column. Values with different upper case letter superscripts differ significantly $(P<0.05)$ between in vitro humoral immunity assessment against homologous and heterologus antigen cross-response within the same vaccinated groups.]

3.5. Assessment of specific cellular immune responses: There were significantly high $(P<0.05)$ cellular immune responses in all the immunized rohu $\left(G_{1}\right.$ to $\left.G_{6}\right)$ of $R_{1}$ and $R_{2}$ groups in contrast to the control $\left(\mathrm{G}_{9}\right)$ and Incomplete Freund's Adjuvant and normal saline solution injected rohu $\left(\mathrm{G}_{7}\right.$ and $\mathrm{G}_{8}$ ) while assaying in vitro proliferation of fish kidney leukocytes stimulated specifically by three different antigenic preparations and also non specifically by Con-A (Table 2). Significantly high $(P<0.05)$ in vitro cellular responses in terms of SI values were found in fishes vaccinated with outer membrane protein $(0.466 \pm 0.013)$ followed by somatic antigen along with Incomplete Freund's Adjuvant $(0.458 \pm 0.016)$ and outer membrane protein along with Incomplete Freund's Adjuvant (0.433 \pm 0.015$)$, while the homologous antigen was used as a stimulating antigen in fish kidney leucocytes culture in tissue culture plate. In most of the cases, highest in vitro cellular response of vaccinated fish kidney leukocytes were found in homologous antigen-stimulated leukocytes as shown in Table 2. Kamilya et al. ${ }^{[15]}$ also found higher in vitro antigen-specific responsiveness of catla (Catla catla Ham.) leucocytes where mushroom glucan and bovine lactoferrin were used as an adjuvant in combination with formalin-killed A. hydrophila for 30 days vaccination studies. Our experiments also supported by Das et al. ${ }^{[6]}$, who studied the immune-effector activities of rohu against A. hydrophila, using intraperitoneal injection $(0.2 \mathrm{ml} /$ fish $)$ with live $A$. hydrophila at a concentration of $1 \times 10^{6} \mathrm{CFU} / \mathrm{ml}$. In this experiment, the higher proliferative responses of all antigen immunized rohu groups than control possibly due to the clonal development of antigen sensitized leucocytes, demonstrated the efficacy of different antigenic preparations of A. hydrophila. Similarly, in some cases, antigens induced a higher response but it was not found statistically significant $(P>0.05)$ that indicated lower degree of memory induction compared with other vaccinated groups. Our results were quite similar to the observations of Bharadwaj et al. ${ }^{[3]}$, who studied the antigen specific lymphocyte proliferation in rohu, challenged with $A$. hydrophila after vaccination with somatic and outer membrane protein antigens of $A$. hydrophila. They found all the vaccinated groups showed higher proliferation $(P<0.01)$ after $10^{\text {th }} \mathrm{d}$ of vaccination than the control. Same antigen-specific proliferative responses have also been noticed in other fish species (Bera et al.) ${ }^{[2]}$, (Kamilya et al.) [15], (Maji et al.) ${ }^{[17]}$. We got significantly higher $(P<0.05)$ lymphocyte proliferation in vaccinated rohu which was also partially supported by Fang et al. ${ }^{[10]}$, who performed the MTT assay to measure the head kidney leucocytes proliferation in blue gourami after $5^{\text {th }}$ week of immunization with adhesin from $A$. hydrophila.

Table 2: Stimulation index (SI) values after $28 \mathrm{~d}$ of immunization

\begin{tabular}{|c|c|c|c|c|c|}
\hline $\begin{array}{c}\text { Different } \\
\text { vaccinated rohu } \\
\text { group } \downarrow\end{array}$ & \begin{tabular}{|c|}
$\begin{array}{c}\text { Antigens used for assessing } \text { in } \\
\text { vitro cellular response of head } \\
\text { kidney leukocytes } \rightarrow\end{array}$ \\
\end{tabular} & $\begin{array}{c}\text { Outer membrane } \\
\text { protein @ } 40 \mu \mathrm{g} / \text { well of } \\
\text { tissue culture plate }\end{array}$ & \begin{tabular}{|c|} 
Somatic protein \\
antigen @ $40 \mu \mathrm{\mu g} /$ well \\
of tissue culture plate
\end{tabular} & \begin{tabular}{|c|}
$\begin{array}{c}\text { Whole cell protein } \\
\text { antigen @ } 40 \mu \mathrm{\mu g} / \text { well } \\
\text { of tissue culture plate }\end{array}$ \\
\end{tabular} & $\begin{array}{l}\text { Con-A @ } 10 \mu \mathrm{g} / \\
\text { well of tissue } \\
\text { culture plate } \\
\end{array}$ \\
\hline \multicolumn{2}{|c|}{ Outer membrane protein } & $0.466^{\mathrm{g} \mathrm{D}_{ \pm 0}}$ & $0.046^{\mathrm{a}{ }^{\mathrm{A}} \pm 0.004}$ & $0.161^{\mathrm{d} \mathrm{B}_{ \pm} \pm 0.012}$ & $0.338^{\mathrm{c}} \pm 0.009$ \\
\hline \multicolumn{2}{|c|}{$\begin{array}{l}\text { Outer membrane protein with Incomplete Freund's } \\
\text { Adjuvant }(1: 1)\end{array}$} & $0.433^{\mathrm{fC}} \pm 0.015$ & $0.091^{\mathrm{b} \mathrm{A}} \pm 0.003$ & $0.343^{\mathrm{e}} \pm 0.016$ & $0.344^{\mathrm{c}} \mathrm{B}_{ \pm 0.014}$ \\
\hline \multicolumn{2}{|c|}{ Somatic protein antigen } & $0.098^{\mathrm{c}} \pm 0.002$ & $0.380^{\mathrm{d} \mathrm{D}_{ \pm}} \pm .008$ & $0.127^{\mathrm{c}} \mathrm{B} \pm 0.004$ & $0.332^{\mathrm{c}} \mathrm{C}_{ \pm 0.008}$ \\
\hline \multicolumn{2}{|c|}{$\begin{array}{c}\text { Somatic protein antigen with Incomplete Freund's } \\
\text { Adjuvant }(1: 1)\end{array}$} & $0.061^{\mathrm{b} \mathrm{A}} \pm 0.004$ & $0.458^{\mathrm{e}} \mathrm{D}_{ \pm 0.016}$ & $0.126^{\mathrm{c} B} \pm 0.005$ & $0.326^{\mathrm{c}} \mathrm{C}_{ \pm 0} .021$ \\
\hline \multicolumn{2}{|c|}{ Whole cell protein antigen } & $0.216^{\mathrm{e}} \pm 0.004$ & $0.325^{\mathrm{c}} \pm 0.012$ & $0.383^{\mathrm{fC}} \pm 0.013$ & $0.204^{\mathrm{b} \mathrm{A}} \pm 0.013$ \\
\hline \multicolumn{2}{|c|}{$\begin{array}{l}\text { Whole cell protein antigen with Incomplete } \\
\text { Freund's Adjuvant }(1: 1)\end{array}$} & $0.133^{\mathrm{d}} \mathrm{A}_{ \pm 0.005}$ & $0.107^{\mathrm{b}} \mathrm{A}_{ \pm 0.005}$ & $0.348^{\mathrm{e}} \pm 0.012$ & $0.126^{\mathrm{a}}{ }_{ \pm 0} \pm 007$ \\
\hline \multicolumn{2}{|c|}{ Incomplete Freund's Adjuvant } & $0.066^{\mathrm{b} \mathrm{B}} \pm 0.004$ & $0.047^{\mathrm{ab} \mathrm{A}} \pm 0.004$ & $0.088^{\mathrm{b} C} \pm 0.004$ & $0.222^{\mathrm{b} D} \pm 0.007$ \\
\hline \multicolumn{2}{|c|}{ Normal saline solution } & $0.054^{\mathrm{ab} \mathrm{AB}} \pm 0.006$ & $0.041^{\mathrm{a}} \mathrm{A}_{ \pm 0.003}$ & $0.061^{\mathrm{ab} B} \pm 0.003$ & $0.228^{\mathrm{b} C} \pm 0.004$ \\
\hline \multicolumn{2}{|r|}{ Control } & $0.038^{\mathrm{a}}{ }^{ \pm} \pm 0.002$ & $0.037^{\mathrm{a}} \mathrm{A}_{ \pm} \pm .003$ & $0.055^{\mathrm{a}} \mathrm{A}_{ \pm 0.007}$ & $0.195^{\mathrm{a}} \mathrm{B}_{ \pm} \pm .007$ \\
\hline
\end{tabular}


[Data $(n=3)$ are presented as mean \pm standard error. Values with different lower case letter superscripts differ significantly $(P<0.05)$ between the control and different treatment within the same column. Values with different upper case letter superscripts differ significantly $(P<0.05)$ between homologous and heterologus in vitro cellular antigenic cross-response within the same vaccinated groups.]

\section{Conclusion}

In short, it may be concluded that outer membrane protein antigen of $A$. hydrophila along with Incomplete Freund's Adjuvant may be considered best for vaccination strategies among the three said antigenic preparations in rohu because it showed higher significant $(P<0.05)$ results in both humoral response and cellular responses in compare to control and also gave $81.81 \%$ RPS after $7 \mathrm{~d}$ of $A$. hydrophila challenge. Highest humoral immune responses was noticed for rohu immunized with whole cell protein antigen mixed with Incomplete Freund's Adjuvant and highest cellular immune responses were observed in case of rohu immunized with $A$. hydrophila outer membrane protein antigen itself. Although, considering the relative percentage of survival, pathological signs during trial period and overall cellular and humoral responses, the outer membrane protein antigen of $A$. hydrophila along with Incomplete Freund's Adjuvant was selected most suitable vaccine for rohu (Labeo rohita) against Aeromonas hydrophila infection.

\section{Acknowledgements}

Authors are grateful to the Hon'ble Vice-Chancellor, West Bengal University of Animal and Fishery Sciences, Kolkata for providing necessary facilities for the experiments.

\section{References}

1. Bastardo A, Ravelo C, Castro N, Calheiros J, Romalde JL. Effectiveness of bivalent vaccines against Aeromonas hydrophila and Lactococcus garvieae infections in rainbow trout Oncorhynchus mykiss (Walbaum). Fish and Shellfish Immunology. 2012; 32:756-761. https://doi.org/10.1016/j.fsi.2012.01.028

2. Bera A, Joardar SN, Abraham TJ, Batabyal S. Dynamic changes in specific immune-effector activities in Aeromonas hydrophila sensitized Catla, Catla catla (Hamilton). Indian Journal of Comparative Microbiology Immunology and Infectious Diseases. 2010; 31:5-10.

3. Bharadwaj A, Abraham TJ and Joardar SN. Immune effector activities in challenged rohu, Labeo rohita after vaccinating with Aeromonas bacterin. Aquaculture. 2013; 392:16-22.

http://dx.doi.org/10.1016/j.aquaculture.2013.01.016

4. Bøgwald J. and Dalmo RA. Review on immersion vaccines for fish: An Update 2019. Microorganisms. 2019; $7(12): 1-28$. https://doi.org/10.3390/microorganisms7120627

5. Chandran MR, Aruna BV, Logambal SM and Michael RD. Immunization of Indian major carps against Aeromonas hydrophila by intraperitoneal injection. Fish and Shellfish Immunology. 2002; 13:1-9. https://doi.org/10.1006/fsim.2001.0374

6. Das P, Joardar SN, Abraham TJ, Kamilya D and Batabyal S. Dynamic changes in immune-effector characteristics of Indian major carp, rohu (Labeo rohita) sensitized with Aeromonas hydrophila. Indian Journal of
Comparative Microbiology Immunology and Infectious Diseases. 2009; 30:45-49.

7. Dash P, Sahoo PK, Gupta PK, Garg LC, Dixit A. Immune responses and protective efficacy of recombinant outer membrane protein $\mathrm{R}$ (rOmpR)-based vaccine of Aeromonas hydrophila with a modified adjuvant formulation in rohu (Labeo rohita). Fish and Shellfish Immunology. 2014; 39(2):512-523. https://doi.org/10.1016/j.fsi.2014.06.007

8. Dash S, Das SK, Samal J, Ojha PK, Patra JK and Thatoi H. Dose dependence specific and non-specific immune responses of Indian major carp (L. rohita Ham) to intraperitoneal injection of formalin killed Aeromonas hydrophila whole cell vaccine. Veterinary Research Communications. 2011; 35:541-552. https://doi:10.1007/s11259-011-9498-2

9. Dubey S, Avadhani K, Mutalik S, Sivadasan SM, Maiti B, Paul J, Girisha SK et al. Aeromonas hydrophila OmpW PLGA nanoparticle oral vaccine shows a dosedependent protective immunity in rohu (Labeo rohita). Vaccines. https://doi.org/10.3390/vaccines4020021

10. Fang HM, Ling KC, Ge R and Sin YM. Enhancement of protective immunity in blue gourami, Trichogaster trichopterus (Pallas), against Aeromonas hydrophila and Vibrio anguillarum by A. hydrophila major adhesin. Journal of Fish Diseases. 2000; 23:137-145. https://doi.org/10.1046/j.1365-2761.2000.00229.x

11. FAO. The State of World Fisheries and Aquaculture 2020. Sustainability in action, 2020. Rome. https://doi.org/10.4060/ca9229en

12. Gudding R, Van Muiswinkel WB. A history of fish vaccination: science-based disease prevention in aquaculture. Fish and Shellfish Immunology. 2013; 35(6):1683-1688. https://doi.org/10.1016/j.fsi.2013.09.031

13. Hu M, Wang N, Pan ZH, Lu CP, Liu YJ. Identity and virulence properties of Aeromonas isolates from diseased fish, healthy controls and water environment in China. Letters in Applied Microbiology. 2012; 55:224-223. https://doi.org/10.1111/j.1472-765X.2012.03281.x

14. Jayasankar P. Present status of freshwater aquaculture in India - A review. Indian Journal of Fisheries. 2018; 65(4):157-165.

https://doi.org/10.21077/ijf.2018.65.4.81300-20

15. Kamilya D, Maiti TK, Joardar SN, Mal BC. Adjuvant effect of mushroom glucan and bovine lactoferrin upon Aeromonas hydrophila vaccination in catla, Catla catla (Hamilton). Journal of Fish Diseases. 2006; 29:331-337. https://doi.org/10.1111/j.1365-2761.2006.00722.x

16. Lowry OH, Rosebrough NJ, Farr AL, Randall RJ. Protein measurement with the Folin phenol reagent. Journal of biological chemistry. 1951; 193:65-275.

17. Maji S, Mali P, Joardar SN. Immunoreactive antigens of the outer membrane protein of Aeromonas hydrophila, isolated from goldfish, Carassius auratus (Linn.). Fish and Shellfish Immunology. 2006; 20:462-473. https://doi:10.1016/j.fsi.2005.06.003

18. Mali P, Maji S, Joardar SN. Antigenic characterization of outer membrane protein of Aeromonas sobria isolated from Goldfish (Carassius auratus L.). The Israeli Journal of Aquaculture - Bamidgeh. 2007; 59(2):91-98.

19. Mzula A, Wambura PN, Mdegela RH, Shirima GM. Current state of modern biotechnological-based 
Aeromonas hydrophila vaccines for aquaculture: a systematic review, BioMed Research International, Article ID 3768948, 2019, 1-11.

20. Ouchterlony O. Antigen antibody and reactious in gels. Acta Pathologica at Microbiologica Scandinavia. 1949; 26:507-515.

21. Plumb JA, Milroy R, Kaye SB. Effects of the $\mathrm{pH}$ Dependence of 3-(4,5-Dimethylthiazol-2-yl)-2,5diphenyltetrazolium Bromide-Formazan Absorption on Chemosensitivity Determined by a Novel Tetrazoliumbased Assay. Cancer Research. 1989; 49:4435-4440.

22. Rasmussen-Ivey CR, Hossain, MJ, Odom SE, Terhune JS, Hemstreet WG, Shoemaker CA et al. Classification of a hypervirulent Aeromonas hydrophila pathotype responsible for epidemic outbreaks in warm-water fishes. Frontiers microbiology. 2016; 7:1615. https://doi.org/10.3389/fmicb.2016.01615

23. Reed LJ, Muench H. A simple method of estimating fifty per cent end points. American Journal of Hygiene. 1938; 27:493-497.

24. Sahoo C, Joardar SN. Potential use of enzyme conjugated anti-carp immunoglobulin in detecting specific antibodies in carp. Indian Journal of Comparative Microbiology, Immunology and Infectious Diseases. 2004; 25:37-40.

25. Sahoo PK, Mukherjee SC, Nayak SK, Dey S. Acute and subchronic toxicity of aflatoxin $\mathrm{B}_{1}$ to rohu, Labeo rohita (Hamilton). Indian Journal of Experimental Biology. 2001; 39:453-458.

26. Saikia D, Kamilya D. Immune responses and protection in catla (Catla catla) vaccinated against epizootic ulcerative syndrome. Fish and Shellfish Immunology. 2012; 32:353-359. https://doi.org/10.1016/j.fsi.2011.11.030

27. Sardar P, Joardar SN, Ganesan P, Abraham TJ. Seroreactivity of somatic soluble proteins of Vibrio alginolyticus. Indian Journal of Fisheries. 2004; 51:239244.

28. Sen SS, Giri SS, Sukumaran V. Immune responses and protection in rohu vaccinated against Aeromonas hydrophila infection. Aquaculture International. 2014; 22:1637-1648.

29. Shoemaker CA, Klesius PH, Evans JJ, Arias CR. Use of modified live vaccines in aquaculture. Journal of World Aquaculture Society. 2009; 40(5):573-585. https://doi.org/10.1111/j.1749-7345.2009.00279.X

30. Sun J, Wang Q, Qiao Z, Bai DQ, Sun J, Qiao X. Effect of lipopolysaccharide (LPS) and outer membrane protein (OMP) vaccines on protection of grass carp (Ctenopharyngodon idella) against Aeromonas hydrophila. The Israeli Journal of Aquaculture Bamidgeh. 2011; 63:1-8. http://hdl.handle.net/10524/22913

31. Swain P, Behura A, Dash S, Nayak SK. Serum antibody response of Indian major carp, Labeo rohita to three species of pathogenic bacteria; Aeromonas hydrophila, Edwardsiella tarda and Pseudomonas fluorescens. Veterinary Immunology and Immunopathology. 2007; 117:137-141. https://doi.org/10.1016/j.vetimm. 2007.02.010

32. Uribe C, Folch H, Enriquez R, Moran G. Innate and adaptive immunity in teleost fish: a review. Veterinarni Medicina. 2011; 56(10):486-503. 